\title{
Village Funds: A Study of Community Village Monitoring
}

\author{
Siti Nuraini ${ }^{1, *}$, Dina Heriyati ${ }^{1}$, Izzato Millati ${ }^{1}$, Aprilia Dwi Puriyanti ${ }^{1}$, Ratna \\ Dwi Lestari ${ }^{1}$
}

\author{
${ }^{I}$ Accounting Department, Economics and Business Faculty, Universitas Airlangga, Surabaya, Indonesia \\ *Corresponding author. Email: sitinuraini@feb.unair.ac.id
}

\begin{abstract}
The village fund is one of the national programs to reduce poverty in rural areas, expand job opportunities by creating businesses in Village-Owned Enterprises (BUMDesa) and improving rural infrastructure. Prioritizing community empowerment, village funds are managed directly by the community. This study aims to find out the monitoring system carried out by the community on the implementation of village funds in East Java from 2015 to 2020 before pandemic Covid-19. This study uses qualitative descriptive research with in-depth interviews, observations and literature studies. The location of the sampling is Regency in East Java. and the sample of this study was 12 districts out of a total of 38 cities/districts. The results of this study indicate that from 2015 to 2020 before pandemic Covid-19, financial reports underwent several changes from a manual system to an online integrated financial system, namely using the village financial system (Siskeudes) or SID (village information system), which shows the role of information technology in management transparency. village funds that can be accessed by the community. Assistance in village funds by the sub-district and the Regional Office for Community and Village Empowerment (DPMD). Meanwhile, the evaluation was carried out with a sample of the Regional Inspectorate, the Provincial Audit and Development Agency (BPKP) and the Supreme Audit Agency (BPK). The general public can report misuse of funds or implementation by calling the hotline at the complaint number. Indications of misuse of village funds can be seen from the limited transparency of the use of village funds, protection against non-existent whistle blowers, and a complaint centre that is only owned by the central government. For this reason, a structured policy is needed to monitor the implementation of village funds from the grassroots level or the general public and government.
\end{abstract}

Keywords: village funds, monitoring system, community village.

\section{INTRODUCTION}

In the era of regional autonomy that emphasizes community empowerment efforts, the role of the Village Government as one of the institutions that plays a role in society and dealing directly with the community is very important, especially as an organizer of development programs. The village government participates in the development process responsibly to improve the people's welfare, one of which is the use of village funds [1]. Village funds are funds sourced from the State Revenue and Expenditure Budget allocated to Villages which are transferred through the regency / city Regional Revenue and Expenditure Budget and are used to fund governance, implementation of development, guidance, community and community empowerment [2]. Village funds are one of the development programs that are expected to be able to reduce development problems such as poverty, income inequality, the low quality of human development, and increased community empowerment in supporting development. [9] stated that with the distribution of village funds, it is expected to encourage equitable development and bring benefits to all village communities. The implementation of village funds has been going on since the beginning of the era of regional autonomy with a different concept from the current village funds. At the beginning of the implementation, village funds came from the Income and Expenditure Budget of each region or better known as the Village Fund Allocation (ADD). The regulations for implementing $\mathrm{ADD}$ are different for each region, different from the implementation of village funds. Since 2015 the government has directly allocated village funds to villages through the regional treasury. At the beginning of its implementation, the national allocation of village funds was approximately 
9 trillion, but in 2016 it had increased by almost 400 percent to 46.98 trillion. The budget for 2018 and 2019 is at 60 trillion for all cities / regencies in Indonesia, respectively. The increase of village funds allocation is carried out to continuing development of the economic potential of the village and focused on empowering the village community. In fact, the increase in allocation of village funds who made by the government is not balanced with good management by the village. It is evidenced by the number of frauds that occur in some areas. The research conducted by [10] stated that the lack of coaching and supervision from the subdistrict head, the Government and Development Security Control Team (TP4), the Village Consultative Agency, and the lack of Human Resources (HR) in the village funds management and village heads are the factors that affecting the several frauds. According to the Indonesia Corruption Watch (2018) report, from 2052017 there were 214 cases of fraudulent implementation of village funds by village heads. From these data, the total violations in East Java were 41 village heads.

Management of village funds based on community empowerment will be able to increase development in the village, especially if the general policy priorities for village funds are meeting basic needs, developing potential local economies, and building village facilities and infrastructure [3], [4]. This is in accordance with the purpose of using village funds, namely as a means to improve the welfare of rural communities, improve the quality of human life and alleviate poverty [2]. Poverty alleviation programs that increase community participation with approach bottom-up and community-based project management have been recognized as elements of the development process because they will have an impact at the micro level in local economic development [5], [6]. The right poverty reduction policies will be able to increase regional economic productivity so as to contribute to national income for developing countries. In addition, poverty reduction program targets in rural and rural areas are more effective in increasing income than target households in urban areas [7], [8].

The management of village funds is carried out independently based on the Village Medium Term Development Plan (RPJM) which has been endorsed together with the Village Consultative Body (BPD) and the Village Government. In accordance with the Regulation of the Minister of Villages, Development of Disadvantaged Areas, and Transmigration of the Republic of Indonesia No. 17 of 2017 concerning Prioritization for the Use of Village Funds in 2018, village funds are used to finance the implementation of programs and activities in the field of village development and empowerment of village communities, which are cross-sectoral, including ; field of activities for superior products in villages or rural areas, Village-Owned Enterprises (BUMDes), rain reservoir, village sports facilities in accordance with village authority. The results of the use of village funds must be published by the village government to the village community in a public space accessible to the village community. In addition, village funds are used to finance village development aimed at improving the welfare of rural communities, improving the quality of human life and reducing poverty.

As an empowerment-based program, the implementation up to the supervision of village funds is carried out by the community. Supervision of village funds is divided into two, namely coaching and evaluation. Direct coaching is carried out by the subdistrict government and the Community and Village Empowerment Service Regency (DPMD), while a sample evaluation is carried out by the Inspectorate, the Provincial Financial and Development Supervisory Agency (BPKP) and the Financial Audit Board Republik Indonesia (BPK-RI). Due to these limitations, comprehensive supervision by the community is required to avoid fraud that occurs during the implementation of village funds. According to the Indonesia Corruption Watch (2018) report, the total violations in East Java committed by village heads amounted to 41 violations. One of the cases occurred at the subdistrict head of Dasuk Village of Pandemany Subdistrict, Pamekasan, East Java who had to be prosecuted for 2 years and 6 months for giving bribes with a nominal of Rp 250 million to the Chief Prosecutor of Pamekasan State to stop investigating the misappropriation of Village Funds Allocation for paving installation and building the village office fences [11]. Another case is the subdistrict head of Banjarsari village, Jetis Subdistrict, in Mojokerto, East Java who was named as a suspect in a corruption case of the distribution of Village Funds and Village Fund Allocation which amount to Rp 487 million in 2015 budget year with a fictitious constructions of paving and the village office gate construction [9].

[11] state that the potential for fraud that occurs in village financial management lies on the side of regulation, governance, and supervision. the results of another study were also conducted by [12], they stated that the competence of the apparatus and the internal control system had a significant influence on the fraud prevention in village financial management. That is 
why in this study we want to know how the monitoring is carried out by the community on the implementation of village funds in the East Java.

\section{METHODOLOGY}

The research used is descriptive qualitative research, namely research that prioritizes the quality of the process rather than just the end result. The approach used in this research is a descriptive approach that emphasizes the individual in understanding and creating his or her daily life. The descriptive qualitative research approach prefers to explore information from sources and respondents directly and interpret it in written narratives so that it is easily understood by other people. Descriptive qualitative research tends to have subjectivity towards respondents so that they are able to see a phenomenon from various angles, namely the object or subject of the factors being studied. The research focus in qualitative research is useful in providing direction during the research process, especially at the time of data collection, namely to differentiate data relevant to our research objectives.

The sampling technique used methods purposive sampling and snowball sampling. Meanwhile, the sampling locations were regencies in East Java that received village funds. From 38 cities/regency in East Java, the samples for this study were 12 Regency, with different location characteristics. The location's determination of this sample is based on the highest village funds for each regional cluster. In this sampling, the East Java region divided into several regional clusters, namely the Madura cluster (Sumenep, Sampang, Pamekasan, Bangkalan), the eastern cluster covering the tapal kuda area (Eastern Pasuruan, Probolinggo, Lumajang, Jember, Situbondo, Bondowoso, and Banyuwangi), the central region (Pasuruan, Malang, Sidoarjo, Batu), the south west region (Blitar, Trenggalek, Tulungagung, Pacitan, Jombang), the north west region (Gresik, Lamongan, Tuban, Bojonegoro), and the Mataram region (Mojokerto, Madiun, Magetan, Ngawi, Ponorogo, Kediri, nganjuk). From each of these regional clusters, the highest village funds were selected to be used as samples. The 12 sample areas are Banyuwangi, Situbondo, Pasuruan, Sidoarjo, Gresik, Lamongan, Blitar, Tulungagung, Jombang, Madiun, Bojonegoro, and Tuban.

The subjects and sources of information for this study were the Government Village Community Service (DPMD) Regency, the Village Head and village officials, and the village community. Subjects and sources of information are based on the actors running the village funds. The method used in this research is in-depth interview, observation and literature study.

\section{RESULTS AND DISCUSSION}

Village funds in East Java have been implemented since 2015 with an allocation of IDR $1,154,892,169,000,-$ which is designated for 29 Regency and 1 municipality. In line with the central government's commitment to increasing village funds, each year the amount of APBN allocation for village funds increases. Consecutively in 2016 amounting to IDR $4,969,123,651,000$, - then increased in 2017 by IDR 6,339,556,181,000, - and in 2018 amounting to IDR $12,708,301,540,000, \quad-$. The government's commitment to making village funds as one of the poverty reduction programs is shown by the increase in the allocation of village funds from the start of implementation.

To get village funds, as an initial condition for the first phase of disbursement, the village must have the APBDes and the previous year's realization of village funds. Meanwhile, for the second and third phase of disbursement of funds, the requirement is a report on the realization of village fund activities. APBDes (Village Revenue and Expenditure Budget) is one of the most important variables in the implementation of village funds. APBDes contains a budget for village development activity plans, starting from infrastructure, personnel expenditure, empowerment, governance and village income sources. APBDes is formed from village planning, namely at the beginning of the new Village Head administration, all components of the village community consisting of the Village Government, BPD (Village Consultative Body) and the Community formulate goals and village development for five years known as RPJMDes (Term Development Medium Plan Village).

During the implementation of village funds, the village fund reporting system undergoes evaluation and development every year. At the beginning of its implementation, village fund reporting used a manual system, including accountability reports and the realization of village funds. Along with the development of an online integrated financial system, village fund reports have used the Siskeudes (village financial system) or SID (Village Information System). In some areas in East Java, the village financial system can be accessed directly by anyone through the website, but there are also those that limit access to financial reporting. Routine reporting of the use of village funds is carried out to the sub-district and DPMD. 
To oversee the implementation of village funds, activity monitoring was carried out by the sub-district and DPMD. The sub-district and DPMD are only the parties that supervise and provide guidance to the implementation of village funds, while the evaluation is carried out by the Inspectorate of Regency, Financial and Development Supervisory Agency (BPKP) and the Financial Audit Board (BPK-RI). Due to limited resources and the large number of villages in one regency, coaching is averaged twice a year using a sample of villages. Likewise, evaluations and examinations were only carried out with a sample of villages and were not carried out as a whole in one regency.

Although the implementation of village funds already has fairly strict rules and principles, in practice there is still fraud or misuse of funds. Problems that often occur in East Java are administrative errors, such as recording financial statements, incorrect input of accounts in the financial system, delays in paying taxes, and the remaining Silpa funds (remaining over budget calculations). Meanwhile, the problems that BPK handled in the form of refunds were mark up in the implementation of infrastructure development, then there were funds that had been disbursed but were not realized because they were brought in by the treasurer. In fact, some cases that have occurred have entered the legal realm with the village head suspect. The results of interviews and field visits indicated that all villages stated that there were no violations or misuse of funds in their place. In accordance with the statement from DPMD regarding the number of cases involving village heads, it is because the responsibility and power of budget users is the village head, while DPMD is only a facilitator and coaching agent.

Transparency in the use of village funds, which is only a formality in regulations, also makes one of the potential misuse of village funds. Transparency at the village level is only limited to the installation of banners or project boards on activities, while not all access to financial administration can have access to this. Only examiners on duty such as inspectorates and BPKP auditors can see the realization of the use of funds directly. The general public is only limited to banners posted in each village hall or during village meetings. The limitations in conducting monitoring and guidance are due to the large number of villages and wide areas and it is anticipated by the presence of independent monitoring from the community. The sub-district, DPMD can receive complaints directly from the community and take appropriate coaching actions. In addition, not all districts have a direct complaint system for the implementation of village funds. The village fund complaint system directly only belongs to the Ministry of Village, Development of Disadvantaged Areas and Transmigration. If there are indications of fraud in the implementation of village funds, the community can report it directly to the center. Although this is part of transparency, with the many reports of complaints received by the Ministry of Villages, the development of disadvantaged areas and transmigration do not make these reports can be handled immediately. According to the Community and Village Empowerment Service, the problem of misuse of village funds is often a follow-up to the findings of the Supreme Audit Agency (BPK), the Development and Finance Supervisory Agency (BPKP) and the District Inspectorate. This happens because the supervision carried out by the community is quite limited. If access to the village financial system online can be opened, the community can directly supervise, but if the village financial system cannot be accessed in general, only the examiner can carry out the evaluation. This statement was also conveyed by the Village Head, that not all people can check the cash books from the village funds. Of the several sample districts in this study, only Sidoarjo Regency provides full access to the use of village funds, and Blitar Regency provides limited access to the community, only total use without being accompanied by details of allocations. While other districts cannot be accessed directly, transparency and use of village funds are only limited to formality in placing billboards and banners in front of the village office.

From the results of the interviews, there were several misuse of village funds that occurred during 2015-2019 in several sample districts. Pasuruan Regency is one of the districts with the most misuse of village funds. The cases that occur are the volume of work for infrastructure activities that does not match the activity plan, the implementation of infrastructure activities that are not carried out by the village, and the misuse of funds that must be handled by the police. In addition, the district average has administrative problems, such as the difference between the purchase of materials for infrastructure development or the village fund reports that are not properly recorded. This indication shows that supervision of village funds is quite limited, only in certain circles, which cannot be carried out by the general public at large. In addition, there is no protection against whistleblowers (reporters of misuse of village funds) and there are no clear rules. From the results of field observations, the implementation of village funds is carried out entirely by the Village Head as the Budget User Authority (KPA) and the village government who has full authority and power 
in the village so that it makes people tend to feel reluctant and reluctant to report misuse of funds.

\section{CONCLUSIONS AND SUGGESTIONS}

Village fund reporting has undergone several changes from a manual system to an online integrated financial system. Fund reports use Siskeudes (village finance) or SID (village information system). The guidance is carried out by the sub-district and the Village Community Empowerment Service in each district. While the evaluation is carried out in a sample manner by the Inspectorate, BPKP (finance and development supervisory agency) and BPK (Financial Audit Board). The general public can report misuse of funds or implementation by calling the hotline at the complaint number. Indications of misuse of village funds can be seen from the transparency of the limited use of village funds in the community, protection against whistleblowers that do not yet exist, and a complaint center that is only owned by the central government. For this reason, a structured policy is needed to monitor the implementation of village funds from the grassroots level or the general public and government. The local government through village community empowerment institutions can provide rules and protection for whistleblowers of misuse of village funds (reporters) with local regulations. In addition, regular training, mentoring, and evaluation for village fund implementers can improve competence and reduce the risk of misuse of village funds. Then, access to transparency of village fund reports by the entire community needs to be done as a form of comprehensive control from the community. This study has research limitations, because this study uses a qualitative descriptive method, the number of respondents is not many so it is still insufficient to describe the actual situation, and this research is more subjective so it cannot describe the overall condition on a wide enough scale. For further research, it is expected to be able to find and explore more deeply and expand the scope of research both in terms of areas and fields that will be used as research objects.

\section{REFERENCES}

[1] N.L.L. Azizi, "Otonomi Desa dan Efektifitas Dana Desa” Jurnal Penelitian Politik, vol. 13, pp. 193-211, 2016.

[2] P.M. Desa, "Disadvantaged PD 2017 Regulation of the Minister of Villages, Development of Underdeveloped Regions and Transmigration of the Republic of Indonesia," No.22, pp. 1-65, 2016.
[3] I. Meutia, and Liliana, "Village Fund Financial Management," Jurnal Akuntansi Multiparadigma, vol. 8, no. 2, pp. 336-352, 2017.

[4] M. Sofiyanto, R.M. Mardani, and M.A. Salim, "Pengelolaan Dana Desa dalam Upaya Meningkatkan Pembangunan di Desa Banyuates Kecamatan Banyuates Kabupaten Sampang," Jurnal Ilmiah Riset Manajemen, vol. 06, no. 4, pp. 28-38, 2017.

[5] M. Sreedhar, "Poverty Alleviation Programmes in India," International Journal Science Research," vol. 6(5), pp. 1127 - 1132, 2017.

[6] S. Gambo, L. Saleh, and A. Jamilu, "Impact of Government Poverty Alleviation Programs on Rural Development in Kaduna and Gombe States: Implications for Public Administration," Ife Social Sciences Review, 2018.

[7] Y. Yang, "The Effect of Poverty Alleviation Policy on the Regional Economic Development: Evidence from the County Level," Modern Economic, vol. 08(01), pp. 1-9, 2017.

[8] K. Lim, L. Lau, and D. Cole, "Differential Impact of a Poverty Alleviation Program Targeting the Ultrapoor in the Philippines,'ICM Research, pp. $1-9,2017$.

[9] Q. Asya'ri, “Analisis Dampak Sosial Ekonomi Pasca Bencana Di Kabupaten Pamekasan (Studi Kasus Banjir, Longsor dan Kekeringan di Pamekasan 2007)," Journal of Management and Accounting, vol. 1, no. 2, pp. 153-168, 2018.

[10] N. Wibisono, and H. Purnomo, "Mengungkap Fenomena Pengawas Publik Terhadap Dana Desa di Kabupaten Madiun," Akuntansi Dan Sistem Informasi, vol. 2(1),pp. 8-19, 2017.

[11] H.Y. Seputro, S.D. Wahyuningsih, and S. Sunrowiyati, "Potensi Fraud dan Strategi Anti Fraud Pengelolaan Keuangan Desa," Jurnal Penelitian Teori dan Terapan Akuntansi, vol. 2(1), pp. 79-93, 2017.

[12] A.T. Atmadja, and K.A.K. Saputra,"Pencegahan fraud dalam pengelolaan keuangan desa," Jurnal Ilmiah Akutansi dan Bisnis vol. 12, no. 1, pp. 7$16,2017$. 